\title{
THE UNIVERSITY ENVIRONMENT: OPPORTUNITIES, CONSTRAINTS AND CHALLENGES FOR SENIOR WOMEN
}

\section{Jenny Neale and Kate White}

Victoria University of Wellington, Australia Faculty of Education and Arts, Federation University, Australia

\begin{abstract}
This paper discusses the way in which the university culture as typified by the work environment and working conditions impacts on women academic staff who have atypical careers. Feminist standpoint theory provides a rationale for using case histories from a New Zealand and an Australian academic to explore the university as a workplace from the perspective of those outside the mainstream and the issues raised in negotiating their place in the organisation. It analyses the wider context of the changes in the tertiary education sector in each country, including the impact of managerialism on women's academic careers and argues that a broad range of approaches can be taken to get into and on in the male-centric university.
\end{abstract}

Key words: Gender, academic careers, outsiders, managerialism.

\section{Résumé}

Le milieu universitaire: opportunités, contraintes et challenges pour les femmes agées.

Cet exposé cherche à démontrer que le milieu universitaire, qu'il s'agisse du lieu de travail ou des conditions de travail, impacte sur les professeures qui ont des carrières atypiques. La théorie de position féministe fournit une base pour l'emploi de cas d'étude dirigés par une universitaire de Nouvelle Zélande et une d'Australie. Ces cas d'étude explorent la situation extérieure à l'intégration et les difficultés à l'encontre de négociations cherchant à les intégrer dans l'organisation. Tenant compte de l'extension du contexte, l'exposé analyse les changements survenus au niveau de l'éducation tertiaire des deux pays y inclut l'impact du manégéralisme sur les carrières du professorat féminin. Il démontre qu'une gamme d'approches leur permet de s'insérer et de collaborer au sein de l'infrastructure universitaire dirigée principalement par les hommes.

Mots clés: genre, carrières académiques, outsiders, manégéralisme.

\section{Resumo}

O ambiente universitário: oportunidades, limitações e desafios para mulheres idosas

O presente artigo discute o modo pelo qual a cultura universitária, tipificada pelo ambiente e pelas condições de trabalho, tem impacto sobre as mulheres académicas com carreiras atípicas. As teorias de pendor feminista fornecem fundamentação para a utilização de histórias de casos de uma académica neozelandesa e uma australiana, com o propósito de explorar a universidade enquanto local de trabalho a partir da perspetiva dos que estão fora do sistema e as questões levantadas na negociação do seu lugar na organização. $\mathrm{O}$ artigo analisa o impacto do managerialismo nas carreiras académicas das mulheres, o contexto mais amplo das mudanças no sector do ensino superior em cada um dos países e argumenta que pode ser utilizada uma ampla gama de abordagens para a integração na universidade dominada pelos homens.

Palavras-chave: Género, carreiras académicas, outsiders, managerialismo. 


\section{Introduction}

Generally, a career has been conceptualised as a linear progression through a particular profession or organisation, proceeding from a sub-ordinate junior role to one with power and privilege (Schein, 1971). However, this model does not necessarily accord with the careers of women which tend to follow more diverse and divergent pathways (Guest and Sturges, 2007; Roberts, 2008).This paper discusses the way in which the university culture as typified by the work environment and working conditions impacts on women academic staff who have atypical careers. Using case histories from a New Zealand and an Australian academic, the university environment is explored from the perspective of those outside the mainstream and the issues raised in negotiating a place to stand looking at the opportunities, constraints and challenges.

\section{Country and Higher Education context}

The formation of the European Union (EU) appears to have been a catalyst for national legislation that ensures member countries focus on the competing demands of paid work and family life. But the development of equal opportunity frameworks in both Australia, with 40 publicly funded universities, and New Zealand, with eight, have been overtly influenced by national politics. Generally when more left wing governments have been in power there has been more commitment to equal opportunities (EO) (White, 2011). Since the early 1990s Australian and New Zealand universities have had equity policies to remove sex discrimination, and they have also put in place a range of initiatives to increase women's representation in academia (Winchester and Browning, 2015). However, national and institutional equity initiatives have not necessarily improved the gendered organisational culture in higher education (HE) in both countries (Fitzgerald and Wilkinson, 2010).

In Australia and New Zealand, HE - originally modelled on the British system though with increasing influence from the USA - has been characterized by a shift to centralised managerial power, replacing the previous collegial model and has occurred at a faster pace in Australia. This is consistent with an increasing movement towards managerialism in universities internationally in the light of state pressure. Ongoing debate about the impact of managerialism on academic autonomy and on university organizational structures has questioned its benefits for academic staff in general and the extent to which collegial or managerial models in particular are more or less helpful to women academics (Bagilhole and White, 2011). Some argue that managerialism makes more explicit the low profile work of women in collegial structures (Brooks, 1997; Eveline, 2004). Others argue that managerialism simply perpetuates masculine discourses and 
practices (Kerfoot and Knights, 1996; Ozga and Walker, 1999). Jenny Neale and Kate White (2012) found that the way in which universities are structured and operate makes gender diversity and management difficult to implement given the competing imperatives of work and other life course trajectories. Sarah Riordan (2011) argues that the necessary social capital to facilitate academic career advancement is easier for men to acquire than women, given the obvious gendered gate-keeping in some organisations and fewer competing imperatives.

Women academics often enter academia later than men and/or have atypical academic careers, with little support for career planning. In both New Zealand and Australia, the accepted career path is from lecturer, to senior lecturer, to Associate Professor to Professor and then to senior management. Given the small number of women at the level of full professor (23 percent in Australia and 18 percent in New Zealand) this means there is a small pool from which to draw on for senior management positions (Neale and White, 2014). Academic women may be building their careers in their 30s and 40s rather than their 20s and 30s and are thus always in the position of trying to catch up with their male colleagues (Bagilhole and White, 2013). Part of the reason for lagging behind is the possible ambivalence women have about the standard 'male' career path. As Louise Morley (2014) asserts women are reflexively scanning leadership and dismissing it as a career option. To what extent the managerial university is a factor in women dismissing leadership roles is not clear. Other factors in the mix are the need to balance family responsibilities, and being encouraged to focus on teaching and pastoral care rather than research. This positioning as 'carers' has been a topic of debate since the 1990s when Meredith M. Kimball (1996: 111) raised the issue of 'political concerns ... around the relationship of care with subordination and oppression». Within the different cultures of paid and unpaid work in which women operate, the contextual imperatives of similarity and difference are played out in a political climate which can reinforce negative stereotypes and demean attitudes and behaviours that are seen as deviant in comparison to the prevailing norm of a linear career.

\section{Standpoint theory}

Feminist standpoint theory is an example of a critical theory that challenges the accepted norms. As such it was developed to critically examine the way in which gender inequality remains a constant in society (Harding, 2004). It «focuses attention on the social conditions.... by which knowledge production and authorisation can be systematically skewed» (Wylie, 2011: 160).Thus, feminist standpoint theorists postulate that knowledge is socially contextualised. Marginalised groups are situated in a position from which they have a unique view of both the wider society and their group, and there is a power imbalance between 
the marginalised and dominant groups (Collins, 2002; Harding, 2004; Hartsock, 1998). An individual's standpoint arises from their particular positioning in society and the intersection of salient characteristics such as gender, race and sexuality (Swigonski, 1993). As women, we are required to have both an understanding of the dominant culture as well as our own. Feminist theorists have focused on a women-centred perspective as the only way of knowing and empowering women so that their voices and narratives are heard in challenges to the male-centric discourses. Mary Swigonski (1993: 179) encourages researchers to «include explicit reflexivity», that is, to explore their own position in the research they carry out. Therefore, using our stories as the case studies of a New Zealand and Australian academic with atypical careers illustrates how accepted norms can be challenged, opportunities created and barriers overcome ${ }^{1}$.

\section{Kate White's academic career}

Kate was born near a regional city in south-east Australia, the fifth of seven children. Despite her parent's poverty and father's ill-health, she completed high school and enrolled at a newer university in Melbourne and graduated with a BA and an MA. She then undertook $\mathrm{ahD}$ at a more prestigious university. By the time she completed her PhD she was married and had a small child, and another on the way. Kate spent the next decade working with her husband in a research consultancy. When she and her husband separated, she initially worked for a parliamentary committee, and then looked for work in the higher education sector often in project management roles. She maintained a profile in academic research, focussing on research on gender in higher education (White, 2013).

\section{Jenny Neale's academic career}

Jenny was the oldest of three children brought up by a solo mother living in an extended household with her maternal grandparents in New Zealand. Jenny left school without qualifying for university, trained as a teacher, got married and had the first of her three children at the age of 19. She began university study at a distance (as an extra-mural student) completing a bachelor's degree and subsequently going on to do honours and a masters' degree when her children were all of school age. She became actively involved with feminist organisations on the basis of social justice and equity, areas where she has focused her own research. Jenny worked as a researcher before taking up her first academic position at the age of 41 , developing and teaching a postgraduate research masters. As a full 
time academic she undertook her PhD in Women's Studies also at a distance. Her management roles included Associate Dean (Research), Deputy Dean of the Faculty of Humanities and Social Sciences and Head of the School of Social and Cultural Studies (Neale, 2013).

\section{Positionality}

Positionality in the organisation can be an opportunity and at the same time an obstacle. Both Jenny and Kate were 'outsiders' in that neither had followed the accepted linear career path. Kate came to embrace the status of being an outsider, just as the women in Jill Blackmore and Judyth Sachs' (2001: 50) study were outsiders on the inside and spoke of how they could 'reposition' in more beneficial ways for themselves and their personal, professional and often feminist political projects. Though originally appointed because of her experience outside the university, Jenny's applied orientation in terms of teaching and research rather than a theoretical academic stance was considered an obstacle, implying that somehow she was less serious about her career. However, in a management position it also gave her an advantage in dealing with both the public sector and other stakeholders because of the networks she had established. It also reinforced for her, that there were a range of employment possibilities available outside of academe. So rather than being an obstacle, being comfortable with the role of outsider can be an asset and used as an opportunity when building an academic career. However, a cautionary note is sounded by Richard Bolden et al. (2012: 37) in that managerialism leads to «diminishing opportunities for academics to self-determine their own sense of direction and in so doing undermining their commitment to the institution and the profession", the sort of dilemma faced at different stages of their career by both Kate and Jenny along with others in marginal positions.

\section{Organisational culture}

Challenging the organisational culture and pushing out the boundaries is problematic for women in higher education. Kate's father had taught her early on to question, even if it made one unpopular, which is more acceptable in some work environments than in others. At the outset of her academic career, as a PhD candidate, there was little appreciation of the systemic nature of the gender discrimination experienced - it was a matter of working hard and dealing with the immediate demands of a young child. But she can clearly remember being angry about the lack of support from the Department. Much later in her career - as acting head of the postgraduate research office and then as a project manager to senior management she did challenge what was often perceived as injustice - but 
not necessarily gendered - which probably was not helpful to her career progression. However, pushing out boundaries is a common experience for older academic women. And as they move into senior positions as «contenders for dominant positions» in HE, they are «subject to marginalisation and attacks on their status» (Cotterill et al., 2007: 192; see also Kloot, 2004)

Perhaps Kate's response to the organisational culture reflected Kathy E. Ferguson's (1984) observation that women can be uncomfortable with bureaucracies that institutionalise modes of domination. However, she used both internal and external networks to sustain her in an often difficult work environment, and tried to support and further the careers of the women that she managed in her various roles. Trusted colleagues would often advise her to keep her head down, keep under the radar of powerful managers, and to simply keep quiet. In this highly volatile environment, there was always the risk of being disciplined by her manager or even sacked. But at the end of the day there was always a sense of needing to live with one's self. These tensions were at times reconciled by active resistance ( $\mathrm{O}^{\prime}$ Connor, 2001) but at other times by enormous frustration that was turned inward leading to stress and illness.

At the time Jenny joined the management structure of the Faculty of Humanities and Social Sciences (FHSS) it was a sub-culture within the larger University culture where women were valued and mentored to succeed, something that was not necessarily true of the University as a whole. (However, this changed when a new woman Dean was appointed who embraced a managerialist approach and positioned herself as 'one of the boys.') The broader university culture became clearer when as Associate Dean (Research) and subsequently Deputy Dean Jenny started to gain more knowledge through membership of pan-university committees. There were individual men who were committed to try and make a difference; however, there were others who believed that merit was genderless and this mind-set did not advance equity issues within the university - especially for women.

As Deputy Dean, Jenny considered that one of her roles was to mentor or at least provide meeting opportunities for the women who were Heads of Schools (HOSs) in FHSS. So for a time this group of women met for breakfast coffee once a month to discuss issues and/or current concerns. Being a woman in these senior management roles was often difficult; Jenny needed to determine which colleagues in similar positions it was safe to discuss difficult issues with, and being careful about involving other colleagues because of confidentiality. These HOSs were strong women. Two subsequently left the university to take high profile jobs based on their areas of expertise. Part of their reason for leaving was the way in which they were treated by the university, where a mix of being patronised and not being heard created intense frustration and an 'undoable' job (see Chesterman et al., 2005).

As Head of School Jenny was able to implement several core principles, such as ensuring that staff had effective performance reviews and applied for 
promotions as soon as they were eligible, rather than waiting until they had ticked all the boxes, as well as seeing the feedback they received as an opportunity to do better next time. She made it clear that when she thought there was perhaps not such a good chance, she would support the individual on the proviso that if they were unsuccessful on this occasion they would use it as a learning experience and try again - and not give up. This proved to be a very successful strategy and with such encouragement staff did very well. Jenny was also able to help younger staff to most effectively manage their parental leave in conjunction with research and study leave, so that particularly women academics did not suffer the double jeopardy accruing from time out of the system and low levels of publishing/doing research, and thereby potentially railroading their careers. The knowledge of the way the system worked and 'how to play the game' was invaluable, along with the necessary touch of cynicism around taking such an approach.

Breda Gray (1994) argues that to remain ambivalent about our position as academic women is necessary as it allows «reflexivity, negotiations, movement and communication». Jill Blackmore and Judyth Sachs (2001: 64, quoting Rose, 1993), perhaps best expresses Kate's and Jenny's personal ambivalence and that of some colleagues when they talk about «ambivalent academics» - those who felt they never «actually participated fully in the academy». Such ambivalence kept them at a distance, «because to get too close and become an insider meant accepting the value systems and governing rules, and required more fundamental compromises that impacted on the central sense of professional and personal integrity, but was a disadvantage in a high-risk taking environment (ibid)»'.Ambivalence as academics can be an essential survival strategy. It allows us to challenge, push boundaries, always questioning, always being on the margins and ultimately maintaining a degree of authenticity.

In these two case studies there was a clear difference in how Kate and Jenny responded to the organisation culture. Kate's career in research/project management and strategic advisor maximised the possibility of strategic influence but lacked a series of clearly articulated career progression steps. Jenny built a career in management, mostly without challenging the organisational culture. These differences in approach had implications for career progression.

As once stable bureaucracies like universities are giving way to new organizational forms, volatility, uncertainty, and complexity are critical factors that characterize the context in which many contemporary leaders operate (Morley, 2014). Women's lives are particularly contextualized and are often nonlinear, representing a complex fabric of personal, professional, and community involvements and responsibilities. Their leadership and personal development are characterized by multiple role patterns and role discontinuities along with the need to maintain a sense of self (Klenke, 2011: 9). Women need to be realistic about higher education organisational cultures and remain slightly sceptical so they can recognise the barriers to achievement, the challenges they face and whether and how they can turn 
these into opportunities on both an individual and university wide basis. However, it is difficult to change the organisational culture (Wajcman, 1998; Burkinshaw, 2015) and women may choose to focus their energies on relationships in which they can be powerful and effective, building productive collaborations with male colleagues, and how to maintain power (Marshall,1995). In dealing with this challenge, Alice Eagly and Linda C. Carli (2007) emphasise the importance of maintaining a sense of authenticity, especially as a leader.

Harriet Minter (2015) reports on research which explores assumptions that women want better work life balance and to spend more time with their children which results in 'benevolent sexism' as career decisions are being made for them on this basis. She also suggests that women step off a particular career path when they gauge that their current situation will not change and look elsewhere for job satisfaction. This stresses the importance of asking women themselves what they want. Universities invest a great deal of energy in reassuring staff that they are committed to equity and diversity. But until women in Australasian universities reach 50 per cent of all full professors across all disciplines in all universities and it is estimated that will take another 40 odd years (Chesterman and Ross, 2006) - one must always be wary of a culture that perpetuates inequity. Women must keep speaking out and challenging this culture. The under-representation of women in the professoriate has huge implications for what universities value as new knowledge, and particularly scientific excellence and innovation.

\section{Conclusion}

A linear academic career eluded Kate - as it eludes many other academic women - partly due to lack of support and opportunities, and partly to the difficulties of juggling strategic career planning and family responsibilities. Added to this was a sense of ambivalence and distrust of the gendered organisational culture in which she was required to build her career. Nevertheless, in embracing what opportunities were offered she was prepared to take risks in her career -to push the boundaries that could have resulted in being disciplined - propelled by the knowledge that in this world we often do not get a second chance.

Taking up a career at the university combined Jenny's two original careers, that of teaching and research, and added a management dimension - the part of her that likes to make things work efficiently. With an applied rather than theoretical background and focus she could work across the sectors and that was an advantage in terms of the diversity in her career. Jenny's career has zig-zagged within the pervasiveness of inequality and the institutional basis for gender discrimination. It reminds us that each succeeding generation of young women needs to understand where women in academe have come from and how far we yet have to travel. 
Both women developed academic careers in a climate of increasing managerialism which, in their experience, did not benefit women. It led to heavier workloads, lack of recognition for ivory basement leadership (Eveline, 2004) and difficulty for women in being head and valued (Blackmore and Sachs, 2007). It also led to greater stress in women's working lives and more difficulty in balancing work and other responsibilities (Bagilhole and White, 2013).

Women's networks play a key role in careers in higher education as well as in the work done outside the HE sector. Both Jenny and Kate were actively involved with feminist and political activities in the pursuit of equity and social justice that provided personal affirmation which could then be carried into their respective university settings. As Felizitas Sagebiel (2005) argues, women in senior HE positions form their own women's networks because they are largely excluded from male networks. These networks make a difference by providing support at a personal, professional and political level. Women need to have the confidence in themselves to believe that they can achieve senior roles, and apply for them. Just believing that hard work brings its own rewards does not result in promotion or being noticed. People will have different ways of attaining their goals and a culture that appreciates difference and diversity is crucial.

Melissa Benn (2015) emphasises that pay transparency, paid work breaks for both men and women, tougher equal rights accountability; establishment of clear targets to achieve parity, and a focus on fixing the system rather than the individual all need to occur before more women move into positions of power. As Natalie Fenton (2003: 13) highlights, the "nature of the academic environment binds men into a hierarchical fraternity and marginalizes women» and is one of the key challenges confronting women in institutions of higher learning. Moreover, changes in $\mathrm{HE}$ are reinforcing competitive values which can be the antithesis of women's working style (O'Connor, 2014). Women undertake the housework of academe and while it may be satisfying in itself, it is time intensive and not helpful in terms of career progression (Barrett and Barrett 2011: 147). It is only at the very senior levels that this becomes an opportunity rather than a barrier to success. Therefore, it is crucial for women to decide how to spend their time in academia because of the consequences resulting from the way in which their time is apportioned. Providing the equity dimension for university committees may be useful in terms of expanding networks and finding out how the university system works but too much time spent on such activities detracts from research and publishing which are essential for promotion. Furthermore, we need to be aware that women are promoted to undoable executive positions - the "glass cliff" (Ryan and Haslam, 2005) - when the organisation is in a crisis or problematic situation.

While our stories are specific to us and cannot necessarily be extended to characterise particular national contexts, they can be interpreted as a reflective process in which we as academic women are making a contribution to the broader research field of gender and HE. Our stories suggest several themes. The first 
is that positionality can be an opportunity or an obstacle and that being an outsider, for example, can offer benefits. Secondly, women need to navigate an often gendered organisational culture and at the same time maintain a sense of balance and authenticity by exploring strategies that enable them to be effective. This study therefore makes a contribution to our understanding of women in higher education in indicating that women with atypical careers can have successful academic careers despite the difficult organisational culture.

Feminist standpoint theory provides a framework for examining accepted orthodoxy from a legitimated position on the margins. Women are in a minority in senior academic positions in the university which is regarded as an elite environment. While the position of women is changing there are still challenges that need to be addressed, especially around fixing the system rather than the individual. Our experiences indicate that being different and doing things differently can be successful. Barriers, opportunities and challenges can at times seem to be one and the same depending on positionality. So, what may be construed as a barrier at one university may be a challenge at another depending on the perspective and whether the emphasis is on a deficit model (concentrating on women's 'lack' of attributes for a successful career) or not (looking at the benefits of difference). The stories of individuals set within the standpoint theoretical context takes the critical focus away from the individual so that the wider picture becomes evident thus making it possible to address systematic issues around equity rather than the individual considering they are solely responsible.

\section{References}

Bagilhole, Barbara; White, Kate (eds.) (2011), Gender Power and Management: a cross cultural analysis of higher education, Basingstoke, Palgrave Macmillan.

Bagilhole, Barbara; White, Kate (eds.) (2013), Generation and Gender in Academia, Basingstoke, Palgrave Macmillan.

Barrett, Lucinda; Barrett, Peter (2011), «Women and academic workloads: Career slow lane or Cul-De-Sac?» Higher Education 61, 141-155.

Benn, Melissa (2015), «Man-Made: Why So Few Women Are in Positions of Power by Eva Tutchell and John Edmonds» - review The Guardian 18 June, accessed 3 August 2015 http://www.theguardian.com/books/2015/jun/18/man-made-so-few-women-are-positions-power-eva-tutchell-john-edmonds-review

Blackmore, Jill; Sachs, Judyth (2007), Performing and reforming leaders: Gender, educational restructuring, and organisational change, Albany, State University of New York Press.

Blackmore, Jill; Sachs, Judyth (2001), «Women leaders in the restructured university», in Ann Brooks e Alison Mackinnon (eds.), Gender and the Restructured University, Buckingham, Society for Research into Higher Education and Open University, 45-66.

Bolden, Richard, Gosling; Jonathan, O'Brien; Anne, Peters; Kim, Ryan; Michelle K. Haslam S. Alexander; Longsworth, Luz; Davidovic, Ann; Winklemann, Kathrin (2012), Academic Leadership: Changing Conceptions, Identities and Experiences in UK Higher Education, London, Leadership Foundation for Higher Education. 
Brooks, Ann (1997), Academic Women, Buckingham, Society for Research into Higher Education and Open University.

Burkinshaw, Paula (2015), Higher Education, Leadership and Women Vice Chancellors; fitting into communities of practice of masculinities, Basingstoke, Palgrave.

Chesterman, Colleen; Ross-Smith, Anne; Peter, Margaret (2005), «"Not doable jobs!": Exploring senior women's attitudes to academic leadership roles», Women's Studies International Forum 28, 163-180.

Chesterman, Colleen; Ross-Smith, Anne (2006), «Not tokens: reaching a «critical mass» of senior women managers», Employee Relations 28(6), 540-552.

Collins, Patricia (2002), Black Feminist Thought: Knowledge, Consciousness, and the Politics of Empowerment ( $2^{\text {nd }}$ ed.) Abingdon, Routledge.

Cotterill, Pamela; Hirsch, Maureen; Letherby, Gayle (2007), «Three ages of women: Age and generation in the academy». In Pamela Cotterill, Susan Jackson \& Gayle Letherby (eds.), Challenges and Negotiations for Women in Higher Education, Life Long Learning Book Series, Dordrecht, Springer, 9, 183-200.

Eagly, Alice; Carli, Linda C. (2007), «Women and the Labyrinth of Leadership», Harvard Business Review, September, 63-71.

Eveline, Joan (2004), Ivory Basement Leadership, Nedlands, University of Western Australia Press.

Fenton, Natalie (2003), «Equality will not be achieved without the right resources, and laws», Guardian Education, 13. accessd August 2015 http://www.theguardian.com/ education/2003/apr/01/highereducation.educationsgendergap

Ferguson, Kathy (1984), The Feminist Case against Bureaucracy, Philadelphia, Temple University Press.

Fitzgerald, Tanya; Wilkinson, Jane (2010), Travelling towards a mirage? Gender, leadership and higher education, Mt Gravatt, Qld, Post Pressed.

Gray, Breda (1994), «Women in higher education: What are we doing to ourselves?» In Sue Davies; Cathy Lubelska \& Jocey Quinn (eds.), Changing the subject: Women in higher education, London, Taylor and Francis, 75-88.

Guest, David; Sturges, Jane (2007), «Living to work - working to live: conceptualizations of careers among contemporary workers», in Hugh Gunz \& Maury Peiperl (eds.), Handbook of Career Studies, London, Sage, 310-326.

Harding, Sandra (2004), The Feminist Standpoint Reader: Intellectual and Political Controversies, New York, Routledge.

Hartsock, Nancy (1998), The Feminist Standpoint Revisited and Other Essays, Colorado, Westview Press.

Kerfoot, Deborah; Knights, David (1996), «The best is yet to come? The quest for embodiment in managerial work», in David Collinson \& Jeff Hearn (eds.), Men as managers, managers as men: Critical perspectives on men, masculinities and management, London, Sage, 78-98.

Kimball, Meredith M., (1996), Feminist Visions of Gender Similarities and Differences, Bingham NY, Harrington Park Press.

Klenke, Karin (2011), Women in Leadership: Contextual Dynamics and Boundaries, Bingley, Emerald Group Publishing Limited.

Kloot Louise (2004), «Women and leadership in universities: a case study of women academic managers», The International Journal of Public Sector Management 17 (6), 470-485 .

Marshall, Judi (1995), Women Managers Moving on: Exploring Career and Life Choices, London, Thomson Learning. 
Minter, Harriet (2015), «Forget flexibility. What working women really want is power», The Guardian 25 ${ }^{\text {th }}$ March. Accessed August 2015. http://www.theguardian.com/ women-in-leadership/2015/mar/25/forget-flexibility-what-working-women-reallywant-is-power

Morley, Louise (2014), «Lost leaders: women in the global academy», Higher Education Research and Development 33(1), 114-128.

Neale, Jenny (2013), «A mature age student», in Barbara Bagilhole \& Kate White (eds.), Generation and Gender in Academia, Basingstoke, Palgrave Macmillan, 65-82.

Neale, Jenny; White, Kate (2014), "Australasian university management, gender and life course issue»', Equality, Diversity and Inclusion: An International Journal 33(4), 384-395 .

Neale, Jenny; White, Kate (2012), Gender and management in universities: life course issues in Australia and New Zealand, invited presentation to the Equity, Diversity and Inclusion Conference, Toulouse Business School, Toulouse, July.

O'Connor, Pat (2014), Management and gender in higher education, Manchester, MUP.

O'Connor, Pat (2001), 'A bird's eye view... Resistance in Academia', Irish Journal of Socio$\log y 10$ (2), 86-104.

Ozga, Jenny; Walker, Lynne (1999), «In the company of men», in Stephen Whitehead e Roy Moodley (eds.), Transforming Managers: gendering change in the public sector London, UCL, 107-120.

Riordan, Sarah (2011), «Paths to Success in Senior Management», in Barbara Bagilhole \& Kate White (eds.), Gender Power and Management: a cross cultural analysis of Higher Education, Basingstoke, Palgrave Macmillan, 110-139.

Roberts, Emma (2008), «Time and work-life balance: The roles of temporal customization and life temporality», Gender, Work, and Organization 15, 430-453.

Ryan, Michelle K.; Haslam, S. Alexander (2005), «The glass cliff: Evidence that women are over-represented in precarious leadership positions», British Journal of Management $16,81-90$.

Sagebiel, Felizitas (2005), «Gendered organisational cultures in engineering. Theoretical reflections on WomEng results and future research perspectives», in Anita Thaler \& Christine Waechter (eds.), Creating Cultures of Success for Women Engineers: Conference Proceedings of Final International Workshop of the WomEng Project, 143-156.

Schein, Edgar H. (1971), «The individual, the organization and the career: A conceptual scheme», The Journal of Applied Behavioural Science 7, 401-426.

Swigonski, Mary E. (1993), «Feminist Standpoint Theory and the Questions of Social Work Research», Affilia 8 (2), 171-183.

Wajcman, Judy (1998), Managing Like a Man: Women and Men in Corporate Management, Cambridge, Polity Press and Blackwell Publishers.

White, Kate (2011), «Legislative frameworks for equal opportunities», in Barbara Bagilhole \& Kate White (eds.), Gender, Power and Management: a cross cultural analysis of Higher Education, Basingstoke, Palgrave Macmillan, 20-49.

White, Kate (2013), «An Outsider in Academia», in Barbara Bagilhole \& Kate White (eds.), Generation and Gender in Academia, Basingstoke, Palgrave Macmillan, 103-126.

Winchester, Hilary P. M.; Browning, Lynette (2015), «Gender equality in academia: a critical reflection", Journal of Higher Education Policy and Management 37 (3), 269-281.

Wylie, Alison (2011), "What knowers know well: Women work and the academy», in Heidi E. Grasswick (ed.), Feminist Epistemology and Philosophy of Science: Power in Knowledge, New York, Springer Science+Business Media. 
Jenny Neale has had a long career in research and evaluation with a focus on gender and social justice. She has also written and taught in the fields of research methodology and evaluation being recognised for her work with the recent award of Fellowship of the Australasian Evaluation Society (FAES). Jenny formerly chaired the Women's Studies Board of Studies at Victoria University of Wellington. Her current research is on women and careers in higher education management, and the way women are portrayed as 'other'.

Kate White is Co-Director of the eleven-country Women in Higher Education Management Network (www.whemnetwork.com) and co-editor (with Barbara Bagilhole) of Gender, Power and Management: a cross-cultural analysis of higher education (2011) (Palgrave Macmillan) and Generation and Gender in Academia (2013) (Palgrave Macmillan). Her current research focuses on gender and higher education, women's academic careers and career progression for women in science. Her latest book is Keeping Women in Science (2015) published by Melbourne University Press.

Endereço: Jenny Neale. Health Services Research, Centre, School of Government, Victoria University of Wellington, New Zealand. jenny.neale@vuw.ac.nz

Artigo recebido em 16 de novembro de 2015 e aceite para publicação em 05 de janeiro de 2016. 